\title{
A cultura do estupro na ficção seriada: os mitos representacionais no seriado Justiça
}
The rape culture in serial fiction: the representational myths in the series Justiça

\section{La cultura de la violación en la ficción seriada: los mitos de representación en la serie Justiça}

\author{
Gêsa Cavalcanti ${ }^{1, a}$ \\ gesakarla@hotmail.com | http://orcid.org/0000-0002-2453-0968 \\ Vinicius Ferreira ${ }^{1,2, b}$ \\ viniciusf.c@hotmail.com | https://orcid.org/0000-0001-7236-4995
}

\footnotetext{
${ }^{1}$ Universidade Federal de Pernambuco, Programa de Pós-Graduação em Comunicação. Recife, PE, Brasil.

2 Universidade Federal do Rio de Janeiro, Programa de Pós-Graduação em Comunicação e Cultura. Rio de Janeiro, RJ, Brasil.
}

a Mestrado em Comunicação pela Universidade Federal de Pernambuco.

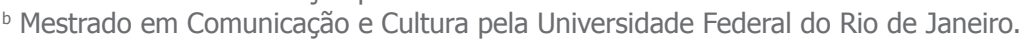

\section{RESUMO}

Este artigo se propõe a analisar a representação e repercussão do estupro na minissérie brasileira Justiça (2016), produzida e exibida pela Rede Globo e de autoria de Manuela Dias. O artigo discute o papel que a representação tem na construção do imaginário coletivo em relação a esse crime, abordando a noção de cultura do estupro, o modo como o crime de estupro é representado na mídia, bem como os mitos perpetuados pelas abordagens feitas. A presente pesquisa apresenta então três momentos de análise: 1) análise da representação do estupro na série; 2) análise da repercussão de tal representação; 3) análise da presença ou ausência dos chamados mitos da cultura do estupro na trama de Justiça.

Palavras-chave: Cultura do estupro; Ficção; Representação; Recepção; Ficção seriada.

\section{ABSTRACT}

This article aims to analyze the representation and repercussion of rape in the Brazilian miniseries Justiça (2016), produced and aired by Rede Globo and written by Manuela Dias. The article discusses the role that representation plays in the construction of the collective imagination concerning this crime, addressing the notion of rape culture, the way this crime is represented in the media, as well as the myths perpetuated by the approaches made. This research then presents three moments of analysis: 1) analysis of the representation of rape in the series; 2) analysis of the repercussion of such representation; 3) analyzes the presence or absence of the so-called myths of the culture of rape in the plot of Justiça.

Keywords: Rape culture; Fiction; Representation; Reception; Serial fiction. 


\section{RESUMEN}

Este artículo tiene como objetivo analizar la representación y repercusión de la violación en la miniserie brasileña Justiça (2016), producida y televisada por Rede Globo y escrita por Manuela Dias. El artículo discute el papel que juega la representación en la construcción del imaginario colectivo en relación a este delito, abordando la noción de cultura de la violación, la forma en que el delito de violación es representado en los medios de comunicación, así como los mitos perpetuados por los enfoques adoptados. A continuación, la presente investigación presenta tres momentos de análisis: 1) análisis de la representación de la violación en la serie; 2) análisis de la repercusión de dicha representación; 3) análisis de la presencia o ausencia de los llamados mitos de la cultura de la violación en la trama de Justiça.

Palabras clave: Cultura de la violación; Ficción; Representación; Recepción; Ficción seriada.

Este artigo compõe o dossiê Feminismos: perspectivas em comunicação e informação em saúde, parte 2.

Contribuição dos autores:

Concepção e desenho do estudo: Gêsa Cavalcanti e Vinicius Ferreira.

Aquisição, análise ou interpretação dos dados: Gêsa Cavalcanti e Vinicius Ferreira.

Redação do manuscrito: Gêsa Cavalcanti e Vinicius Ferreira.

Revisão crítica do conteúdo intelectual: Gêsa Cavalcanti e Vinicius Ferreira.

Declaração de conflito de interesses: não há.

Fontes de financiamento: Fundação de Amparo à Ciência e Tecnologia de Pernambuco (FACEPE); Conselho Nacional de Desenvolvimento Científico e Tecnológico (CNPq); Coordenação de Aperfeiçoamento de Pessoal de Nível Superior (Capes).

Considerações éticas: não há.

Agradecimentos/Contribuições adicionais: não há.

Histórico do artigo: submetido: 10 abr. 2021 | aceito: 15 jul. 2021 | publicado: 31 ago. 2021.

Apresentação anterior: Parte pontual da análise, presente no tópico 4 desse artigo, referente a presença e ausência de mitos da cultura do estupro em Justiça aparece em um trabalho publicado por Cavalcanti (2017) nos anais do Intercom.

Licença CC BY-NC atribuição não comercial. Com essa licença é permitido acessar, baixar (download), copiar, imprimir, compartilhar, reutilizar e distribuir os artigos, desde que para uso não comercial e com a citação da fonte, conferindo os devidos créditos de autoria e menção à Reciis. Nesses casos, nenhuma permissão é necessária por parte dos autores ou dos editores. 


\section{INTRODUÇÃO}

$\mathrm{O}$ crescimento do número de estupros divulgados ${ }^{1}$ e a repercussão de casos notórios como o estupro coletivo do Rio de Janeiro², em 2016, somados aos dados sobre como a sociedade brasileira interpreta casos como esse - a destacar a pesquisa realizada pelo Fórum Brasileiro de Segurança Pública (FBSP) que afirma que uma em cada três pessoas no Brasil ainda acha que o estupro é culpa da vítima ${ }^{3}$ - apontam para a necessidade de se debater a chamada cultura do estupro. O termo, que surgiu durante a segunda onda feminista nos Estados Unidos na década de 1970, é usado para denunciar naturalizações e comportamentos que relativizam ou silenciam a violência sexual contra a mulher.

A cultura do estupro é produzida por um complexo dispositivo discursivo nutrido pelas mais diversas instituições e seus atores sociais, tais como o Estado, o sistema judiciário, o jornalismo, as instituições religiosas, os conglomerados televisivos, a indústria do cinema, a indústria pornográfica etc. Aqui vamos nos ater à representação midiática e, mais especificamente, à representação do estupro na ficção seriada pelas emissoras de TV. Assim, antes de seguirmos, faz-se necessário deixar claro que este estudo não analisa estupros, mas, sim, a representação deles e quais interpretações são suscitadas, em particular no que se refere à saúde da mulher.

A análise da representação do estupro na ficção seriada, tema deste artigo, não busca aferir se a narrativa audiovisual foi capaz de captar a 'Verdade' sobre o ato da violência sexual e os seus desdobramentos. O que nos move, enquanto analistas da representação, é demonstrar quais efeitos de sentidos são produzidos e quais relações de poder são estabelecidas durante o processo representacional do estupro.

Ao se voltar para a interpretação do material produzido e exibido pela Rede Globo, especificamente no seriado Justiça (2016), a pesquisa, somada às repercussões dos episódios nas redes sociais, visa compreender como determinadas propostas de representação do estupro são reconhecidas como legítimas, enquanto outras, não. Esse percurso permite perceber as disputas presentes na representação midiática e a sua inserção na vida social.

Partimos do pressuposto de que representar "nunca é uma ação neutra, mas uma prática de produção discursiva que produz efeitos de sentido sobre a cultura, a moral, a ideologia, e a política, isto é, sobre a realidade como parte instituinte do processo de construção social do que entendemos por realidade" (SACRAMENTO; BORGES, 2020, p. 12). Dessa forma, o estudo da representação midiática é fundamental para a compreensão da cultura do estupro porque, em uma sociedade cada vez mais midiatizada como aquela em que vivemos, os meios de comunicação assumiram a centralidade na produção dos sentidos socialmente compartilhados (SODRÉ, 2009, 2014). São as representações reiteradas que consumimos e partilhamos pelas mídias que autenticam o que é considerado aceitável ou indizível, normal ou anormal, punível ou plausível de gratificações.

Falando especificamente sobre o estupro, Winn (2011) afirma que a mídia perpetua mitos que alteram negativamente a percepção da audiência. Para compreender essa afirmação é importante ter clareza sobre o que estamos entendendo enquanto mito e a sua relação com a comunicação. Os mitos contemporâneos seriam algo próximo a uma 'representação coletiva' em que a cultura é transposta em natureza, ou seja, o

1 Segundo o relatório do $14^{\circ}$ Anuário Brasileiro de Segurança Pública (2020) a cada oito minutos foi registrado um crime de estupro no ano de 2019. Foram no total 66.123 boletins de ocorrência de estupro ou de estupro de vulnerável. A maior parcela dessas vítimas é do sexo feminino, cerca de $85,7 \%$.

2 Às vésperas dos Jogos Olímpicos no Rio de Janeiro, em 2016, viralizaram na internet vídeos e fotos de um estupro coletivo, em que a vítima, uma adolescente de 16 anos, foi estuprada por mais de 30 homens. O caso ganhou notoriedade internacional. Apenas três homens envolvidos diretamente com a gravação e a divulgação do material foram indiciados. Dois foram condenados a mais de 15 anos de prisão, enquanto o terceiro suspeito segue foragido.

3 Pesquisa realizada pelo Datafolha, encomendada pelo Fórum Brasileiro de Segurança Pública (FBSP) e divulgada em agosto de 2016. 
que seria o resultado do produto histórico de disputas sociais é apresentado como 'evidente por si mesmo'. Esse tipo de representação adquire forma, por exemplo, nos estereótipos (BARTHES, 2010, 1977).

A mídia, principalmente a televisiva, éa substituta moderna das grandes narrativas míticas que organizam a percepção do mundo. O imaginário passa a ser articulado por leituras da realidade que vemos, assistimos, pelas telas. As imagens estereotipadas e ampliadas pela mídia transformam discursos em verdades e, assim, legitimam as políticas públicas e de subjetividade. Dessa forma, a comunicação midiática, ao mobilizar o debate e produzir o vínculo social, indica as possibilidades de apreensão e ação da/na realidade. Isto é importante porque, na área da saúde, por exemplo, a comunicação atravessa os processos de elaboração, implementação e gestão de políticas de saúde coletiva (ARAÚJO; CARDOSO, 2007).

A violência, incluindo a violência sexual sofrida por mulheres, é um problema de saúde pública ${ }^{4}$ que, para ser compreendido, precisa considerar diversos fatores sociais (GUERRERO, 2000). No Brasil, foi sancionada, em 2013, a Lei 12.845, que estabelece protocolos para garantir o atendimento integral e gratuito às vítimas de estupro pelo Sistema Único de Saúde (SUS). Contudo, muitas mulheres não são atendidas ou sofrem algum tipo de violência durante o atendimento. Isso ocorre, em certa medida, porque os profissionais da saúde são também interpelados pelos mitos da cultura do estupro. Sarti (2009), por exemplo, demonstra que os valores culturais que circulam sobre um ideal de vítima ${ }^{5}$ e de algoz são determinantes para definir o acesso e o tipo de tratamento que será conferido pelo campo da saúde. Para a autora, a imagem estereotipada da vítima condicionaria o atendimento humanizado.

O imaginário cristalizado sobre a vítima não permite, por exemplo, que um homem heterossexual que tenha sofrido agressões sexuais seja reconhecido institivamente como vítima de estupro e receba tratamento adequado. Enquanto sociedade, naturalizamos a imagem da vítima de abusos sexuais como sendo a da mulher, a da criança e a do homossexual - 'simplesmente é assim'. Esses mitos sobre a violência sexual provocam inúmeras consequências, entre as quais a naturalização dos papéis de gênero e sexualidade.

Os mitos sobre o estupro funcionam seguindo uma maquinaria moral que prevê uma conformidade dos papéis esperados para a tríade sexo-gênero-desejo, de forma que uma mulher que sofreu agressões sexuais pode não ser reconhecida como vítima caso tenha determinadas posturas (a roupa que veste, os locais que frequenta etc.) ou demonstre um certo tipo de relação com o agressor (marido e mulher, namorados etc.).

O reflexo da cultura do estupro na atuação dos profissionais da saúde é somente um dos múltiplos efeitos provocados pelos sentidos que circulam baseados nos seus mitos. O que podemos observar nessas narrativas sobre o estupro é a atuação do "monstro" - que para Barthes (2013, p. 15) dorme em cada signo, o estereótipo. O processo de fixar representações rígidas sobre determinados aspectos sociais faz com que os sujeitos, em todas as esferas da vida humana, sejam reduzidos a estereótipos. Isso implica uma significação baseada em atributos homogeneizados e naturalizados (SACRAMENTO; BORGES, 2020). Dessa forma, uma mulher que não segue as condutas esperadas estaria se distanciando da figura ideal de vítima e se aproximando de uma postura de risco iminente, na qual se torna a culpada pela agressão.

Os produtos de entretenimento, por se destinarem a um consumo desatento, se tornam espaços privilegiados de circulação e consumo acrítico dos estereótipos que auxiliam a urdir o tecido da vida cotidiana. Pelo espetáculo do entretenimento o público consome imagens cristalizadas das emoções demasiadamente humanas (crueldade, justiça, presunção, repulsa etc.). As cenas de estupro, em especial, fornecem o que Barthes (2010) denomina espetáculo do excesso, muito próximo ao teatro antigo, em que

4 O Conselho Diretor da Organização Pan-Americana da Saúde decretou, em reunião realizada em 1993, que a violência é uma prioridade de saúde pública nas Américas. A Organização Mundial da Saúde, em sua 49a Assembleia, realizada em 1996, aprovou uma resolução similar, consolidando o entendimento de que a violência é um problema de saúde pública (GUERRERO, 2000).

5 A palavra 'vítima' possui uma dupla dimensão em nosso trabalho. Ela pode se referir tanto à pessoa física que sofreu as agressões sexuais como a um lugar simbólico que funciona como um operador de sentidos, estabelecendo expectativas e consequências, para os sujeitos que estão sob sua insígnia. 
todos os elementos em cena fornecem explicações exageradamente visíveis. Os corpos, os gestos, as roupas e os comportamentos evidenciam e justificam os papéis assumidos pelos personagens.

Nesse aspecto, as encenações midiáticas míticas têm ligação direta com a naturalização da cultura do estrupo. Os mitos sobre o estupro, ao se perpetuarem, reforçam a culpabilização da mulher e a fetichização do não consentimento, contribuindo para despolitização da pauta - na medida em que atos dessa natureza vão sendo encarados como reflexos de comportamentos ditos como naturais. Nesses casos, a interpretação da representação extrapola os significados que estão em cena (como a dor, a violência, a subjugação). O público, ao reconhecer se tratar de um estupro, aciona valores para a produção de sentido amparados em sistemas mais amplos, como o machismo e a misoginia, que tendem a naturalizar tais acontecimentos (BARTHES, 2010).

Dessa forma, perceber quais narrativas míticas sobre o estupro estão presentes na fiç̧ão seriada e o que elas produzem em termos de efeito de sentido no público se torna objetivo central para a pesquisa. Propomos, assim, analisar a construção do arco do estupro na trama do seriado Justiça (2016) e o modo como ele foi sendo recebido pelo público, buscando entender quais sentimentos e conversações essa representação traz à tona. A inclusão das percepções da audiência é fundamental, por compreendermos que a produção dos sentidos não é exclusiva de quem produz a mensagem - ao contrário, ela ocorre na relação estabelecida com os receptores (VOLÓCHINOV, 2018).

Iremos analisar a representação do estupro da personagem Débora Carneiro (interpretada por Luisa Arraes) na minissérie brasileira Justiça, contextualizando a maneira como a trama se enquadra dentro do ecossistema midiático televisivo. Escolhemos esse programa por duas razões: a primeira delas é a repercussão da série, que teve grandes índices de audiência ${ }^{6}$, tanto nos moldes tradicionais quanto nas redes sociais on-line. A segunda razão diz respeito ao modo como o estupro aparece nesta trama, não sendo o mobilizador da narrativa de outro personagem. Desse modo, Débora é a protagonista de sua história, não sendo, portanto, um caso de women in refrigerators, termo que, como afirmam Rodrigues, Menezes e Bandeira (2016), surgiu no final da década de 1990, a partir do descarte de personagens femininas de revistas em quadrinhos, cuja supressão acontecia para benefício do plot. Num espectro mais amplo, o termo continua, até hoje, sendo usado para falar de situações nas quais uma personagem feminina é morta, estuprada ou incapacitada com o propósito de afetar ou motivar um personagem masculino.

Para realizar a análise proposta, optamos por uma arquitetura metodológica da pesquisa fundamentada no diálogo entre o pensamento barthesiano e o pensamento feminista. Essa base epistemológica nos direcionou a problemas de pesquisa que demandavam o uso de ferramentas metódicas particulares que permitissem perceber os efeitos de sentido na representação do estupro em Justiça (BARBOSA, 2020). Dessa forma, produzimos, em um primeiro momento, uma análise descritiva do enredo somado à recepção dos telespectadores/internautas sobre os desdobramentos da trama. Para aferir os sentidos produzidos pela audiência, coletamos e agrupamos em tipos de reação recorrentes os comentários feitos pelos internautas na rede social Twitter, escolhida por ser um dos principais espaços usados pelos telespectadores para comentar produtos televisivos. Os tweets foram coletados com a ferramenta NodeXL7, após a exibição de cada um dos quatro episódios de Justiça em que o enredo abordava a trama do estupro.

Por fim, após identificarmos as formas como o estupro foi tratado e seus desdobramentos junto ao público, buscamos perceber a presença e a ausência dos mitos da cultura do estupro, como apresentados em Harding (2015), na trama de Justiça, bem como analisar as repercussões de tal representação. De toda

6 Segundo dados do Ibope referentes à grande São Paulo e ao Rio de Janeiro, a média de audiência do seriado representou um crescimento superior a 100\% com relação aos índices habitualmente alcançados pela emissora na mesma faixa de horário em que o seriado foi exibido.

7 O NodeXL é uma ferramenta de coleta, análise e visualização de gráficos de rede que opera na plataforma do Microsoft Office Excel. Com ele, coletamos cerca de 2.000 comentários por capítulo usando a combinação de marcadores: 'Débora' e 'Justiça'. 
forma, inicialmente traçaremos uma radiografia da presença da cultura do estupro no ecossistema midiático para então apresentar e analisar a forma particular como o abuso sexual é representado e significado por sua audiência na minissérie.

\section{A CULTURA DO ESTUPRO E A FICÇÃO SERIADA}

A cultura do estupro, como já pontuado, é a normalização de atos de violência sexual. Buchwald, Fletcher e Roth (2005) a definem como um complexo de crenças que encorajam a agressão sexual e dão suporte à violência contra mulheres ${ }^{8}$ : "[...] violência é vista como sexy e sexualidade como violência" (BUCHWALD; FLETCHER; ROTH, 2005, p. XI). Essa cultura se estabelece quando os estupros são tratados como situações triviais, quando ocorre a culpabilização da vítima, numa distorção perversa em que se naturaliza o absurdo - as mulheres 'pediram por isso', pois não se vestem de forma adequada, andam sozinhas etc.

Dessa forma, a culpabilização das vítimas justifica a ação dos homens. Como afirma Meyers (1997), essa lógica social parte de uma premissa para explicar o estupro que que diz: "ele é homem". Isso significa que se as mulheres derem aos homens a oportunidade de estuprá-las, eles, naturalmente, farão isso. Ou seja, os homens são entendidos como seres irracionais, incapazes de ter controle frente à manifestação da 'natureza' de macho, enquanto as mulheres são ensinadas a evitar provocar esse instinto masculino incontrolável.

Outro elemento de perpetuação da cultura do estupro é a objetificação sexual das mulheres. Mas a cultura do estupro está ainda relacionada à recusa do reconhecimento de que determinados comportamentos são danosos e podem contribuir para atos de violência sexual, tal como a permissão tácita de que meninos, por serem meninos, podem ter comportamentos violentos (boys will be boys). Ou ainda, como afirma Magestro (2015), está relacionada à disseminação de uma 'sabedoria' convencional que diz às meninas que os meninos puxam os seus cabelos e as provocam porque gostam delas. Menos inócuo, afirma a autora, é o fato de que a desigualdade salarial baseada em gênero ainda é um problema significativo na maioria dos setores da força de trabalho, assim como a sub-representação das mulheres na política e em muitos campos profissionais. Esse contexto determina, portanto, o "que é um comportamento apropriado para mulheres, que espaços são adequados para que as mulheres ocupem e existam” (MAGESTRO, 2015, p. XV).

Dessa forma, fica claro que o espectro que a cultura do estupro abrange é muito maior do que aquilo que a palavra parece suscitar em nossas mentes. Tudo isso cria uma desigualdade de poder que é refletida no modo como a mulher é vista pelo homem. Como afirmou a escritora feminista norte-americana Andrea Dworkin em um discurso feito na Midwest Regional Conference of the National Organization for Changing Men em 1983:

Os homens acreditam que têm o direito de forçar sexo, que eles não chamam de estupro. E é uma coisa extraordinária tentar entender que homens realmente acreditam que têm o direito de bater e de machucar. E é igualmente extraordinário tentar entender que homens realmente acreditam que têm o direito de comprar o corpo de uma mulher com o propósito de fazer sexo: e que isso é o seu direito. (DWORKIN, 1988, p. 164)

Dessa maneira, estamos falando sobre um 'projeto de estupro', que vulnerabiliza a condição de se ser mulher e viriliza a 'natureza' de se ser homem. Os traços mais profundos da subjetividade feminina, a sua 'essência', seriam produzidos por um processo de emasculação incansável que torna a mulher permanentemente vulnerável, amedrontada. Por isso, o estupro é um programa político (DESPENTES, 2016).

8 Talvez seja necessário deixar claro que o estupro não acontece apenas com mulheres e que quando o feminismo fala sobre a cultura do estupro não está dizendo que as mulheres são mais importantes que qualquer outra vítima, mas, sim, que as mulheres são o “alvo principal das mensagens e dos mitos que sustentam a cultura do estupro” (HARDING, 2015, p. 5). 
Ingenuamente, enquanto sociedade, tendemos a considerar que o estupro é algo raro, fora da sexualidade, até mesmo evitável, quando, na realidade, ele se encontra no centro do sistema sexual. O estupro é a representação crua e direta do exercício do poder, ele designa o dominador e organiza as regras do jogo para anular o outro (DESPENTES, 2016).

Nessa lógica, o estupro é um organizador social. Nele, o sexo masculino declara seu poder ao afirmar que tem todos os direitos, que tem a força para fazer o outro se sentir inferior, culpado e degradado. Assim sendo, constrói-se uma mística masculina perigosa, brutal, incontrolável por natureza. Para a mulher, nesse cenário, cabem o pudor, a impotência e, em última instância, a vergonha irreparável de ser violentada. Sob o véu do estupro - esse ato condenável, obscuro, sobre o qual não se deve falar -, encontram-se os resíduos sintetizados do conjunto de crenças fundamentais sobre a virilidade masculina e a vulnerabilidade feminina (DESPENTES, 2016).

Em sua denúncia à cultura do estupro, Dworkin (1988) chamou a atenção para as representações que são feitas na cultura midiática como, por exemplo, a revista pornográfica Hustler da editora Larry Flynt Publications; destacou também que há "os escritores que acham que estupro é maravilhoso" (DWORKIN, 1988, p. 167). Em The Night and Danger, a autora ressaltou o modo como a indústria cultural romantiza os predadores. A figura do vampiro, segundo Dworkin, é um bom exemplo dessa romantização. Magestro (2015) também chamou a atenção para o modo como as narrativas nas séries televisivas e nos filmes contribuem para reforçar os mitos em torno do estupro.

Interessa-nos aqui falar um pouco desses mitos, pois eles servirão de guia durante a análise da representação do estupro na série em questão. Segundo Harding (2015), o termo "mitos do estupro" ("rape myths") tem origem no movimento feminista dos anos 1970 e vem sendo refinado por cientistas sociais desde então. E, embora os "mitos do estupro" variem entre sociedades e culturas, existem características padronizadas, apresentadas por Harding (2015): eles culpam a vítima pelo estupro, expressam uma descrença nas acusações de estupro, exoneram o culpado e passam a ideia de que apenas um certo tipo de mulher é estuprada.

Essas quatro 'características' salientadas por Harding (culpar a vítima, expressar descrença, exonerar o culpado, julgar a vítima) foram expandidas e organizadas em sete mitos: 1) Ela pediu por isso; 2) Não foi de fato um estupro; 3) Ele não teve a intenção de fazer isso; 4) Ela queria; 5) Ela está mentindo; 6) Estupro é algo trivial; 7) Estupro é um evento desviante. Harding (2015) destaca que alguns desses mitos claramente se contradizem, mas deixaremos para explorar melhor as características deles quando formos analisá-los à luz do objeto de estudo deste trabalho.

O que nos interessa agora é pontuar que poucas pesquisas analisam a presença desses mitos na programação televisiva, mas que aquelas que a abordam mostram que os mitos prevalecem na representação. Um exemplo é o estudo realizado por Brinson (1990, 1992). A autora observou em sua pesquisa as narrativas de 26 programas televisivos que faziam referência ao estupro. Analisando-as, percebeu que 46\% das histórias sugeriam que as vítimas 'pediram por isso', 42\% sugeriam que a vítima queria ser estuprada e $38 \%$, que ela estava mentindo. Brinson $(1990,1992)$ argumenta que os "mitos do estupro" são evocados e articulados com mais frequência que qualquer desconstrução da cultura do estupro. De fato, entre o material analisado pela autora apenas $38 \%$ das histórias dos programas de TV analisados apresentavam uma abordagem que oferecesse qualquer tipo de oposição ao mito de que a vítima estava pedindo por isso.

Voltamos à questão da representação lembrando que os produtos culturais têm impacto no tecido social. O recorte que se faz de algo, a imagem que se constrói sobre um objeto ou uma temática, pode determinar "quem ascende, quem descende, quem é incluído, quem é excluído" (HALL, 2016, p. 10) - o que é reforçado, o que é desconstruído. Dessa forma, as representações de casos de estupro podem ser problematizadas e podem operar mudanças na sociedade, mas podem ser também parte do problema. 
O seriado Twin Peaks ${ }^{9}$, por exemplo, é considerado um clássico da televisão por sua abordagem narrativa complexa e seu sucesso de audiência, mas é preciso considerar o modo como a adolescente Laura Palmer (Sheryl Lee), a vítima, que é encontrada morta, nua e enrolada em um plástico, é representada. Para Ahlf (2013), a série é um ótimo exemplo de como a cultura do estupro é bem reproduzida pela mídia de massa. Essa afirmação se dirige, principalmente, ao modo como Twin Peaks sugere que a vítima deu ao seu estuprador uma 'oportunidade', quando ela se envolveu com atividades ilegais e perigosas - esse dado favorece que a audiência culpe a adolescente por ter sido estuprada e assassinada.

Programas como Twin Peaks e Guerra dos Tronos ${ }^{10}$ representam o estupro como um acontecimento frequente em suas tramas, mas não se importam em explorar as consequências psicológicas, emocionais e sociais do estupro. Em Guerra dos Tronos, por exemplo, a personagem Sansa Stark (Sophie Turner) é estuprada pelo marido Ramsay Bolton (Iwan Rheon) no sexto episódio da quinta temporada (Unbowed, Unbent, Unbroken). O ato parece ter dois principais objetivos: 1) reforçar a vilania de Ramsay Bolton; 2) humanizar um outro personagem (Theon Greyjoy, interpretado por Alfie Allen), que é forçado a assistir. A câmera, por sinal, foca mais na expressão do homem que assiste à cena do que no estupro em si. ${ }^{11}$

O estupro de Sansa parece ser mais sobre Theon do que sobre a violência por ela sofrida. É a partir desse momento que o personagem volta a agir, um caso claro de narrativa que explora o fenômeno chamado women in refrigerators. Tanto a demonstração da vilania de um personagem quanto o momento de redenção do outro poderiam se fazer através de outros recursos. Além disso, embora o 'uso' do estupro seja problemático, a cena da 'consumação' do casamento de Ramsay e Sansa poderia ter sido apresentada de forma implícita. A cena, conforme foi produzida, pode ainda ser justificada como necessária para que Sansa se sentisse estimulada à vingança contra Ramsay, para recuperar as terras da sua família, mas essa justificativa se enfraquece quando se considera toda a história até aquele momento, pois fica claro que Sansa já tinha razões suficientes para se vingar.

Ao analisarmos Justiça refletiremos não só sobre essas questões, como também sobre o protagonismo, a sensibilização e os impactos do ato na vítima, sobre as representações da vítima e do estuprador; e sobre a presença/ausência dos já citados 'mitos do estupro'.

\section{OS EFEITOS DE SENTIDO SOBRE O ESTUPRO EM JUSTIÇA}

A minissérie Justiça, produzida e exibida pela Rede Globo entre agosto e setembro de 2016 (totalizando vinte episódios), contou quatro histórias - ambientadas na mesma cidade (Recife) ao mesmo tempo - que giram em torno da ideia de justiça. Essas histórias questionam diversas esferas do sistema judiciário, como, por exemplo, a capacidade de reparar ou não os danos causados mediante as penas aplicadas, a integridade do próprio processo jurídico e até dos agentes da lei. Ao perpassar essas questões, o seriado aborda a relação entre justiça e vingança.

Cada uma das tramas que compõem o mosaico do seriado foi exibida de forma sequencial, em determinado dia da semana. Nas segundas-feiras, por exemplo, contou-se a história de Vicente (Jesuíta Barbosa), que passou sete anos na cadeia após assassinar sua noiva Isabela (Marina Ruy Barbosa). Liberto, ele tenta conseguir o perdão de Elisa (Debora Bloch), sua ex-sogra, e seguir sua vida com a família que construiu enquanto esteve preso. Apesar de as histórias se desenrolarem de forma independente, elas se entrecruzam em determinados momentos.

9 Twin Peaks é uma série de televisão norte-americana criada por Mark Frost e David Lynch e exibida pela ABC entre 1990 e 1991. 10 Guerra dos Tronos é uma série de televisão norte-americana baseada na série de livros homônima. Foi produzida e exibida pelo canal HBO entre 2011 e 2019.

11 É preciso ressaltar aqui que, ao criticar esse ponto, não estamos defendendo que o estupro deveria ter sido mostrado de forma mais explícita, mas, sim, pontuando que o foco sai da vítima para o personagem Theon. 
Este estudo foca na trama exibida às quintas-feiras, que aborda duas questões principais: preconceito racial e estupro. O enredo conta a história de Rose Silva dos Santos (Jéssica Ellen) e Débora Carneiro (Luisa Arraes), melhores amigas desde a infância. Rose, uma jovem negra, é a primeira de sua família aprovada em um vestibular e decide comemorar sua aprovação com Débora em uma festa. Em meio a uma batida policial, Rose é presa com drogas, enquanto Débora é liberada, claramente por questões raciais.

Após a prisão de Rose, o telespectador passa a acompanhar a saga da jovem no sistema prisional; já Débora, um tempo depois da prisão da amiga, terá sua vida marcada por um estupro. A história então avança sete anos, o tempo de encarceramento de Rose. As amigas enfim se reencontram e partem, inicialmente juntas, em busca do homem que violentou Débora.

O estupro de Débora ocorreu de dia, durante um bloco carnavalesco pelas ruas de Recife. Acompanhamos Débora se afastar da multidão para fumar maconha. Pouco depois de entrar em um beco, ela é abordada por um homem. Deduzindo ser um assalto, ela pede para que ele leve qualquer coisa contanto que não a machuque. O homem deixa claro que não quer dinheiro: "Eu não sou ladrão, não, dona.” Ele arrasta Débora para um lugar mais reservado, a espanca e a estupra.

A cena do estupro é violenta e afasta o crime da ideia de sexo. A finalidade não é de prazer, pois, embora o estuprador faça questão de dizer 'Finge que tá gostando ou isso não vai acabar', sua fala deixa claro o quanto aquilo é sobre poder, controle. A expressão no rosto de Débora é sempre de dor, desespero. Confirmamos esse efeito de sentido quando observamos os comentários: muitos dos telespectadores afirmaram que a cena fora muito forte, repulsiva, e ainda assim, majoritariamente, elogiaram a atuação e a necessidade de mostrar a agressão. A audiência afirmou, em seus comentários no Twitter, que a cena estava muito próxima da realidade.

A sequência de imagens da cena de estupro explicita o que Barthes (2010) chama de espetáculo do excesso. Os corpos, as roupas e os gestos de Débora e de seu agressor permitem que a audiência anteveja o papel que cada um vai desempenhar no desencadear da ação. O público se vê diante da impotência da vítima que, já no chão, após receber um soco e totalmente imobilizada, bate violentamente com os braços contra o chão sujo para que todos entendam o caráter intolerável do acontecimento. O agressor, enquanto isso, se apresenta como repugnante e exibe um sorriso mordaz frente à tentativa de reação da vítima.

Um ano depois, Débora enfrenta as consequências emocionais e físicas do estupro; mesmo após várias tentativas e tratamentos, ela e o marido, Marcelo (Igor Angelkorte), não conseguem engravidar. Cabe aqui destacar outra implicação da diferenciação entre estupro e sexo em Justiça, a personagem e o marido fazem sexo, e não há nenhuma menção a problemas nesse sentido. 
Reciis - Revista Eletrônica de Comunicação, Informação \& Inovação em Saúde, Rio de Janeiro, v. 15, n. 3, p. 614-635, jul.-set. 2021 [www.reciis.icict.fiocruz.br] e-ISSN 1981-6278

\section{Aug 26}

Essa cena do estupro... Não dá pra não se impactar. É, chorei. \#Justiça

4h 2 47

Red Lip C iftieodary - Aug 26

Fiquei bem mal com essa cena de estupro,sério,infelizmente é a realidade o que me deixa mais mal ainda \#Justiça

Sh 197

\section{Lunara frangand - Aug 26}

Eu não tenho estrutura pra ver cena de estupro 2 \#Justiça

h 27103

FAll Furatins - Aug 26

a cena do estupro foi realmente $\mathrm{mt}$ forte, quase $\mathrm{n}$ consigo aguentar \#justiça

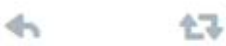

Aug 26

Que cena forte essa do estupro \& \& \#justiça
4
나 1
(1) 2
$+\infty$

Cutruvia crphlasidal - Aug 26

Tnho nojo đ cena d estupro e do estupro em si pq além d ser nojento só mostra cmo a mulher é vista pela sociedade: um objeto sexual \#Justiça

ค $17 \begin{array}{llll}24 & 10 \quad 00\end{array}$

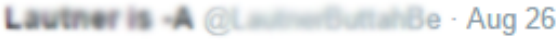

A cena do estupro fica na cabeça, pq por mais q a gente saiba que existe, muitas vezes preferimos fingir o contrário \#Justiça
4
눈 5
5
$\bullet$

\section{Lilly al ary - Aug 26}

sobre a cena do estupro estou aguardando comentarios do tipo "mas tb olha a roupa dela" "se tivesse em casa n teria acontecido" \#Justiça
\& 2
เ7
(1) 4 ?

2 Bea follows

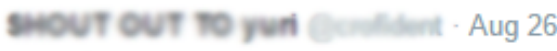

quando passou a cena do estupro eu fiquei todo arrepiado e comecei a chorar, mesmo sendo ficção é a realidade de algumas mulheres \#Justiça
\& 1
ㄴา 5
10
$\bullet$

Mylian Cryprolliveira_. Aug 26

Sério, ainda estou chocada com a cena do estupro. Que vontade de chorar e de matar aquele estuprador!!! \#Justiça

Figura 1 - Internautas comentam no Twitter a cena do estupro de Débora, que foi ao ar em 26 de agosto de 2016 Fonte: capturado pelos autores.

Quando Rose sai da cadeia, Débora conta à amiga o estupro que sofreu e é estimulada a procurar o estuprador. Débora fica animada com a possibilidade de fazer justiça, mas, quando revela a Marcelo a ideia de encontrar o criminoso, o marido se mostra contrário. 


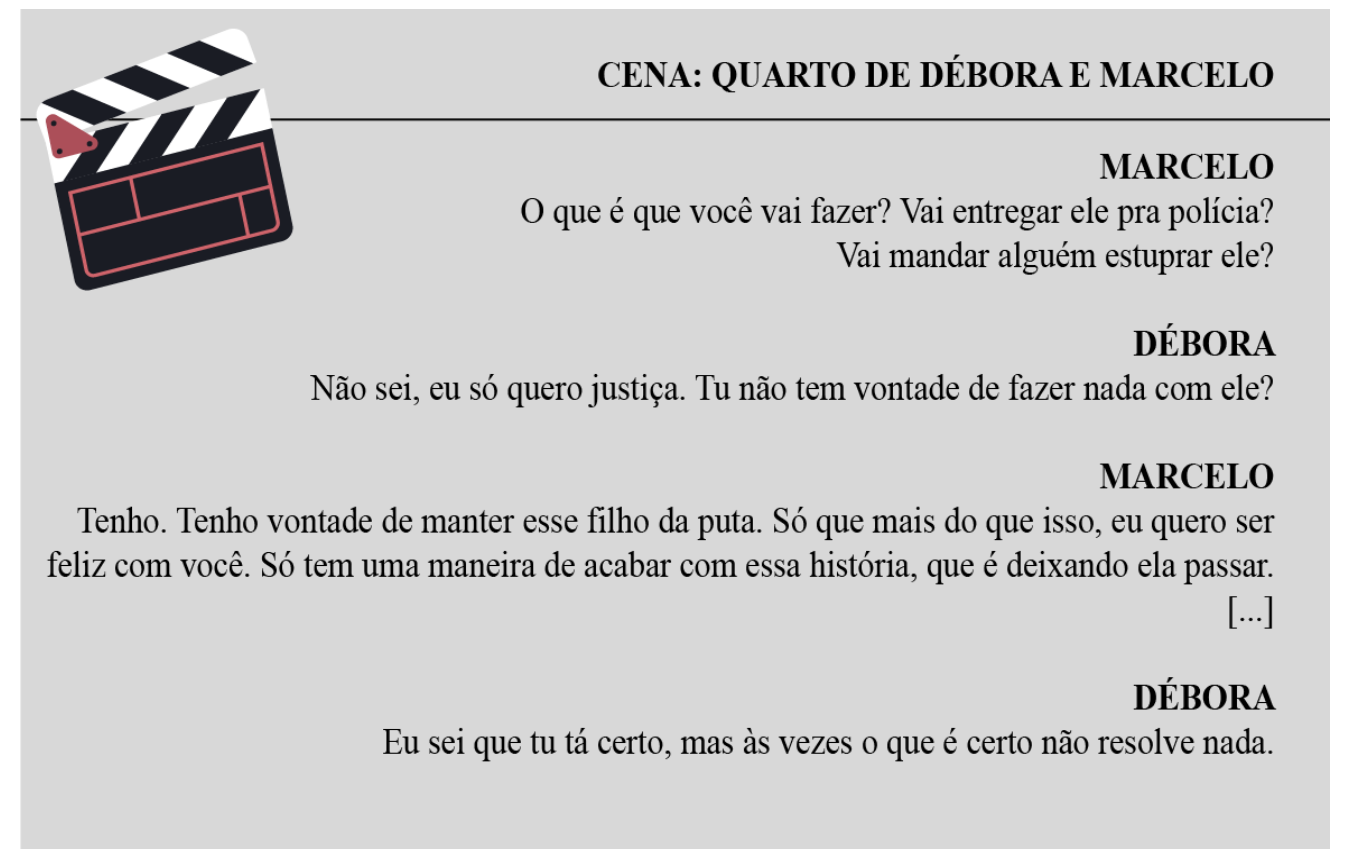

Figura 2 - Transcrição de diálogo entre Débora e Marcelo

Fonte: elaboração da autora.

Posteriormente, Débora e Marcelo saem para jantar com um casal de amigos e Débora traz o assunto à tona perguntando o que o amigo faria, caso sua mulher fosse estuprada. Quando o amigo responde que mataria o estuprador, Débora dispara: "Eu fui estuprada e Marcelo quer que eu simplesmente esqueça o que aconteceu." Em outro momento, o casal volta a conversar sobre o assunto e Marcelo afirma que a esposa precisa esquecer o acontecido e que o estuprador não pode roubar a felicidade dela.

Diante do acontecimento traumatizante do estupro, a trama apresenta dois caminhos. No trilhado por Débora, o estupro se torna memória superativada, insuperável. Seu marido sugere, então, que ela esqueça, que 'apague' o estupro para seguir com a vida. Despentes (2016) aponta que esses são dois movimentos recorrentes e interligados para mulheres que sofreram abusos sexuais: eles demonstram a impossibilidade de se ignorar os efeitos do estupro e o desejo de esquecê-lo para que não provoque mais tristeza para si e para o outro.

Nessa perspectiva, o estupro seria um acontecimento disruptivo que permearia com reflexos da violência a vida de quem foi violentada. Ele agiria como um acontecimento fundador que ao mesmo tempo desfigura e constitui o sujeito. A experiência deixa uma memória indelével da concreta aproximação com a morte, com um estado de submissão frente ao ódio desumanizado do outro. Essa consciência da impotência provocada pelo estupro retornaria recorrentemente, apesar de todos os esforços para superála. O desejo do esquecimento se apresenta, assim, como um imperativo para tentar apagar essa ferida aberta e obscura. Asfixiar essa lembrança seria uma maneira de não retornar a esse lugar, de não acionar o aparelho de vigilância feminino e também de não lembrar ao outro a posição em que você foi colocada (DESPENTES, 2016).

Essa dinâmica para com a memória traumática do estupro instauraria um estado obsessivo em sua vítima (DESPENTES, 2016). Isso acontece porque tanto na memória superativada quanto na busca pelo recalque as lembranças traumáticas não são elaboradas. Esses mecanismos de defesa psíquica, incapazes de por si sós elaborarem o acontecimento traumático, fazem com que ele retorne de forma escamoteada na vida ou prendendo o sujeito ao trauma (FREUD, 1990, 1996a, 1996b).

A não elaboração da memória e, por conseguinte, o seu uso literal fazem com que o presente e o futuro se tornem submissos ao acontecimento traumático do passado. A vítima não se desliga dele, e o impacto 
emocional doloroso passa a integrar o presente. Com isso, o passado não tende a aspirar à justiça, mas a provocar um desejo de vingança (TODOROV, 2000). A trama de Justiça passa, então, a abordar um dilema - qual seria a escolha de Débora com relação a sua memória traumática? Reconhecida a impossibilidade do perdão, todos, inclusive Débora, passam a orbitar entre a defesa de um caminho pautado pela vingança ou o esquecimento forçado.

O primeiro personagem que enfaticamente questiona Débora sobre o papel que o estupro assume em sua vida é o seu marido, Marcelo. Em diversos momentos, ele tenta dissuadi-la da ideia de encontrar o estuprador. Frente a esse direcionamento da trama, a maior parte do público reagiu criticando Marcelo por não ajudar a esposa; outros, em menor proporção, acreditam que o personagem é sensato e que está tentando mantê-la a salvo. Destacamos ainda que há um evidente desconforto com o papel de gênero - a audiência parece esperar que, por ser homem, Marcelo tome a frente da busca, mate o estuprador e 'salve' a esposa.

Para tentar fazer com que Débora desista de procurar o estuprador, Marcelo sugere que ela realize sua vontade de ser mãe adotando uma criança. Débora promete esquecer a história e se acerta com o marido, até que lê no jornal a notícia de que uma adolescente foi estuprada no mesmo local que ela fora. Ela decide ir até o hospital visitar a garota. A adolescente está muito machucada, abalada. É nítida a emoção de Débora ao ver aquela cena, mas, ainda assim, ela descreve o homem, o modo como ele agia, as coisas que falou, e a menina confirma a descrição feita por Débora. Com a ajuda de Rose, Débora consegue fazer um retrato falado do estuprador. Mais uma vez é visível a dor da personagem ao se lembrar do homem. Quando a imagem fica pronta, somos levados ao estuprador, Osvaldo (Pedro Wagner).

No episódio seguinte, Débora dá sinais de mais traumas emocionais. Rose e Marcelo a encontram no banheiro, fazendo uma tatuagem em si mesma, fazendo com que a audiência questione a sanidade da personagem e gerando uma mudança no modo como o público recebe o personagem Marcelo, que passa a ter mais apoiadores. Apesar disso, encontramos internautas criticando a representação de Débora como louca ou afirmando que vítimas de estupro precisam de compreensão, não, de julgamento.

No desenrolar da história, Marcelo encontra o retrato falado do estuprador na bolsa de Débora e pede o divórcio, mas não sem antes eles terem uma conversa na qual Débora tenta explicar ao marido sua incapacidade de esquecer o que aconteceu. Na conversa, a personagem descreve o estupro, e a descrição comoveu os telespectadores - alguns chegaram a afirmar que a descrição é ainda mais forte que a cena do estupro em si. Essa informação nos permite lembrar que existem outros recursos para retratar um estupro e impactar a audiência. A série Shetland ${ }^{12}$, por exemplo, tem um episódio inteiro sobre um estupro sem exibir $o$ ataque, e ainda assim consegue impactar a audiência.

12 Shetland é um drama policial escocês produzido pela ITV e exibido pela BBC One desde 2013. 


\section{CENA: DÉBORA E MARCELO, ELEVADOR}

\section{DÉBORA}

Eu queria tanto que tu entendesse, mas eu não consigo explicar. Por que a ordem natural é essa, né? Deixa pra lá, esquece, não fala desse assunto. Mas não dá pra esquecer. Eu lembro de cada detalhe, de tudo. A blusa verde dele, a bermuda jeans, tinha poça de água assim do meu lado, o teto descascado. Eu desmaiei no primeiro soco e quando eu acordei ele já tinha tirado a minha calcinha, ele me batia na cara e pedia pra fingir que tava gostando, tudo que eu queria era esquecer, era mudar de cidade, mudar de país, morrer, qualquer coisa... mas eu não consigo. E se eu tenho como achar ele, seja porque Rose tá me ajudando, seja porque... eu não vou perder essa chance.

$[\ldots]$

Eu não quero me separar de tu.

\section{MARCELO}

Eu topo qualquer coisa com você. Mudar de cidade (...) mas eu não vou procurar esse cara contigo.

\section{DÉBORA}

Eu não quero mais mentir pra tu, a verdade é que eu não vou desistir de encontrar o homem que me estuprou.

Figura 3 - Transcrição de diálogo entre Débora e Marcelo Fonte: elaboração da autora.

Em seguida, capangas contratados por Débora encontram um homem que acreditam ser o estuprador. Débora deixa o trabalho no meio do expediente para encontrá-los (o que posteriormente acarreta na sua demissão), e chegando lá encontra o homem sendo espancado, mas avisa que aquela é a pessoa errada. Sentindo-se culpada, Débora o convida para se recuperar em sua casa. Enquanto o homem dorme no sofá, Marcelo aparece de surpresa, e, quando Débora explica a situação, ele avisa que ela está passando dos limites, que poderia ter matado uma pessoa inocente. Sem emprego, Débora passa a se dedicar exclusivamente a encontrar o estuprador, mas acaba localizando-o por acaso: ela o reconhece, enquanto ele pinta a fachada de um prédio. Decidida a fazer algo, pede ajuda a Rose que avisa que mudou de ideia quanto a ajudar a amiga. Nesse momento, é reafirmado o protagonismo de Débora como agente de sua narrativa.

Débora continua com sua investigação e consegue finalmente encontrar Osvaldo. Ela o segue pelas ruas, e vemos um pouco mais desse homem. Ele é apresentado como uma pessoa comum, carismática, que tem amigos, que faz bem seu trabalho. A forma como o algoz é representado no seriado se distancia do estereótipo da cultura do estupro. O personagem desconstrói o mito apontado por Meyers (1997) de que os poucos estupradores que existem são sádicos, loucos, psicopatas. Ao não apresentar Osvaldo como uma pessoa doente e atormentada, a minissérie corrobora com o entendimento de que o estupro é um problema cultural, e não uma doença.

Ao perseguir o estuprador, Débora é descoberta por ele. O homem a joga dentro de seu carro e a segura pelo pescoço, questionando o porquê de persegui-lo. Débora então pergunta se ele não a reconhece. $\mathrm{O}$ questionamento aciona um flashback em que a cena do estupro é reexibida, mas dessa vez pelo ponto de vista do estuprador. Nesse momento, novamente, há um cuidado em mostrar o sofrimento da vítima, e não o prazer do homem - mesmo da perspectiva dele o estupro não é erotizado. Débora luta contra o estuprador e consegue fugir, mas não sem antes ser ameaçada por Osvaldo. 
Do ponto de vista da repercussão, os internautas, em sua grande maioria, afirmaram que Débora era culpada, pois, ao procurar insistentemente pelo estuprador, foi pega e quase estuprada novamente. Débora era culpada por ter se colocado nessa situação. Como se, de alguma forma, uma ação dela pudesse justificar um estupro. Fora isso, os comentários coletados destacavam o medo que os telespectadores sentiram quando Osvaldo colocou Débora dentro do carro ou ainda o alívio por ela não ter sido estuprada novamente.

Apesar da busca pelo estuprador, Débora ainda tem esperanças de voltar com o marido e reorganizar sua vida assim que resolver seu passado. Esse desejo é percebido quando ela encontra a assistente social responsável pelo processo de adoção e mostra que tem feito compras para o quarto do bebê. Contudo, Débora arma um plano para tentar encontrar o estuprador e entregá-lo à polícia. Depois disso, decide voltar com o marido e dizer que desistiu de encontrar Osvaldo - e o casal, então, reata. Débora é, nesse e noutros momentos, compreendida pela audiência como mentirosa e manipuladora. Constantemente, ela é exibida bebendo ou fumando e outros personagens, como Celso (Vladimir Brichta) e Rose, a acusam de não estar em seu juízo perfeito. Apesar disso, Débora parece bastante racional ao afirmar que deseja colocar o homem que a estuprou atrás das grades, evitando que ele continue violentando outras mulheres.

Na noite anterior à execução de seu plano, Débora descobre que ela e Marcelo conseguiram adotar uma criança e que a assistente social os visitará no dia seguinte. Débora fica impactada com a notícia, e assistimos a isso numa cena em que ela reflete sobre a vida que terá com sua família, mas também sobre a possibilidade de pegar o estuprador. Ela se lembra de Osvaldo, de suas ameaças, e decide seguir em frente com o plano. Com a ajuda dos capangas arranjados por Celso, Débora leva Osvaldo de volta ao local do estupro. Depois de ser agredido pelos capangas, ele nega o estupro. Débora grita com Osvaldo, que acaba confessando que a estuprou. Provocada, Débora mata o estuprador a pauladas. 


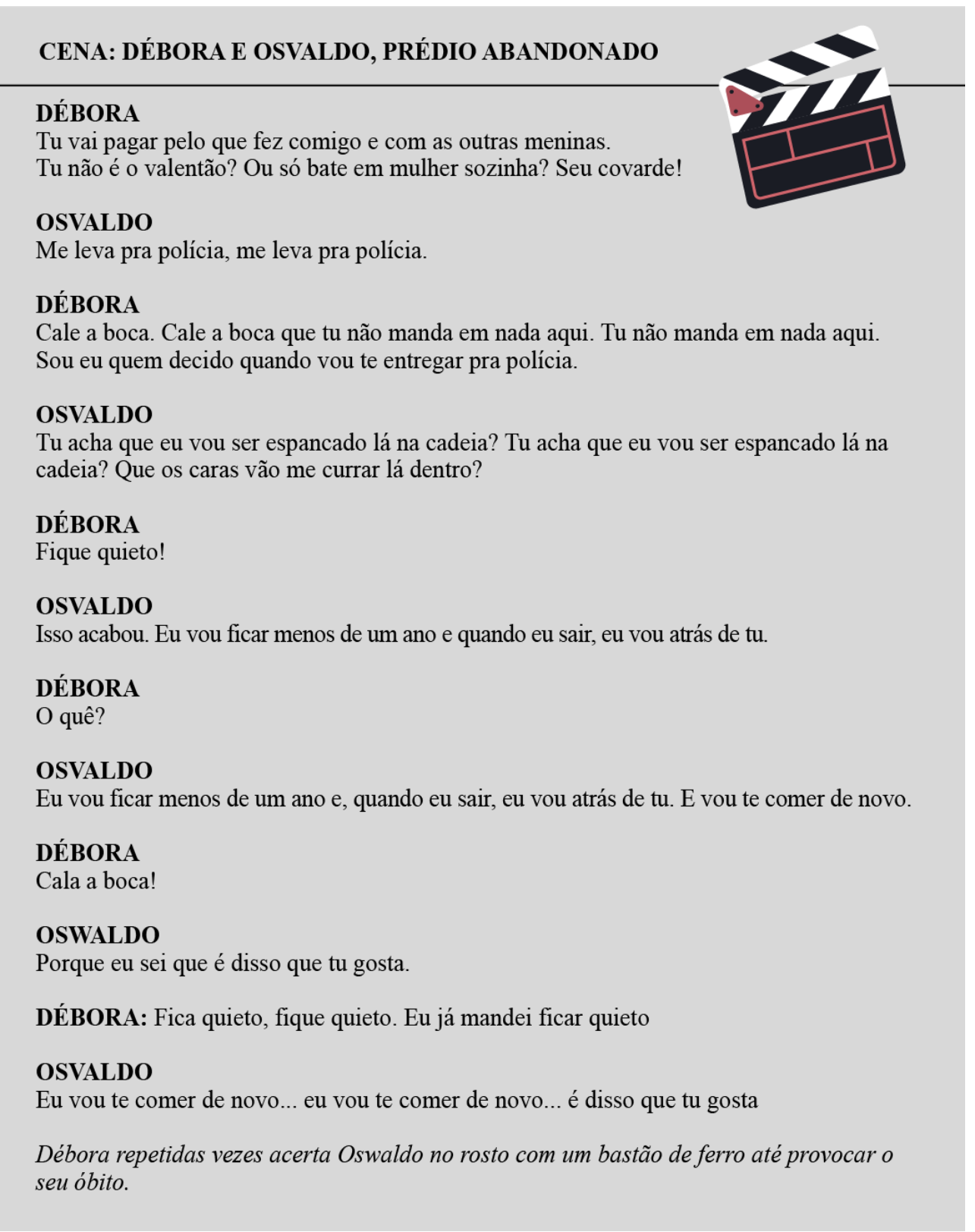

Figura 4 - Transcrição de diálogo entre Débora e Osvaldo

Fonte: elaboração da autora.

O impulso violento de Débora, que resultou na morte de seu agressor, foi desencadeado pelo não reconhecimento por parte de Osvaldo, mesmo após a punição física, de que o estupro que ele havia cometido é um ato moralmente condenável, que infringe a ordem social e que ofende e agride a integridade da vítima. As novas ameaças proferidas demonstravam a aparente incapacidade de correção do estuprador. O escárnio do agressor diante das possíveis sanções que o Estado poderia estabelecer como pena a ser cumprida faz com que Débora não acredite que entregá-lo à polícia resultaria na execução da justiça.

O plano inicial de Débora, ainda que envolvesse métodos ilegais e o abuso de força física, objetivava alcançar a justiça. Para Ricoeur (1995), no processo de busca pela justiça, os reconhecimentos público e pessoal do queixoso como vítima e do acusado como culpado são fundamentais para estimular o trabalho de luto pelo qual o sujeito que teve sua autoestima ferida pode se reconciliar consigo mesmo.

No entanto, Osvaldo não se reconhece como culpado nem reconhece Débora como vítima. Isso impede que ela elabore sua memória traumática. A palavra, no contexto de sansão da justiça, apresenta forte poder 
simbólico de cura, mas Osvaldo impede a efetivação dessa ação. O estuprador continua a violentar a vítima por meio do discurso, é a forma pela qual ele ainda impõe a sua masculinidade viril. Quando Osvaldo não se cala, ele está desacatando a autoridade recém-conquistada por Débora. Em síntese, é o não reconhecimento, por parte de Osvaldo, da sua culpa e do lugar assumido por Débora, que aciona o gatilho disparador da vingança visceral que a vítima inflige ao seu agressor.

Quando Débora não aparece para a reunião com a assistente social, Marcelo começa a procurar pela esposa. Ele acaba chegando ao local no qual ela foi estuprada e encontra a carta de confissão escrita por ela:

"Há dois anos atrás esse homem me violentou, e por causa disso eu não posso mais ter filhos. A polícia não fez nada, ninguém fez nada. Então, eu resolvi fazer. Alguns podem chamar de vingança, eu chamo de justiça. Assumo toda culpa e confesso: "Fui eu que matei ele.' Ninguém me ajudou, não, eu fiz tudo sozinha."

Marcelo vai embora da cena do crime levando a carta, enquanto Débora é mostrada caminhando por uma rodovia com uma bolsa nas costas.

Na carta de confissão, Débora assume o crime que cometeu, apesar de o assassinato ser para ela uma forma de justiça pelo sofrimento que teve de suportar. Ela apresenta o homicídio como a única alternativa possível, já que ninguém havia feito nada que ela julgasse efetivo para encontrar e penalizar o seu agressor. Pela ótica de Débora, o que muitos poderiam entender como vingança era fazer justiça por si própria. Contudo, Ricoeur (1995, p.172) lembra que "a palavra justiça não devia figurar em nenhuma definição de vingança”, pois se trata de processos radicalmente opostos. Na vingança, a vítima movida pela cólera emocional desencadeada pelo crime inscreve a punição na esteira deste, enquanto, na justiça, existe uma justa distância entre o crime cometido e a penalização infligida pela instituição judiciária. A vingança, que tem como raiz o sofrimento, é movida pela violência, enquanto, a justiça reconhece a dor, mas busca erradicar a violência.

A punição ao corpo de Osvaldo, empregada pelos capangas de Débora, seguida pelo seu assassinato faz parte de uma falsa crença, segundo Ricoeur (1995), de que ao fazer o seu algoz sofrer a vítima repararia os danos causados. Mas a punição infligida pela vingança não é capaz de restaurar a realidade para um estado anterior ao crime. A vingança faz uso da violência para combater a violência e, por isso, pode até ser capaz de restabelecer a ordem social, já que a morte do criminoso impede a prática de novos delitos, mas não cicatriza a ferida da vítima, na medida em que não a liberta da memória traumática. Ao contrário, a vingança, por ser movida pela violência, tende a desencadear novas lembranças traumáticas que impedem que a vítima viva um futuro sem os fantasmas do passado.

Analisando a recepção do desfecho, encontramos dois posicionamentos principais: os internautas comemoravam o fato de que Débora finalmente conseguiu fazer justiça, apoiando-a, afirmando que fariam o mesmo e que estupradores merecem a morte. Já um segundo grupo deixava claro que aquilo era vingança, e não justiça. E podemos ainda dividir esse grupo em aqueles que entendiam o porquê da vingança, embora não fossem favoráveis a ela; e outros que criticavam o desfecho afirmando que Débora deveria ter encontrado outra forma de seguir em frente.

\section{OS 'MITOS DO ESTUPRO' EM JUSTIÇA}

Discutida a representação do estupro na narrativa de Justiça, agora nos ocupamos da análise da presença dos mitos referentes ao estupro. Na tabela a seguir, relembramos os mitos já citados, explicamos como eles funcionam e indicamos a presença ou ausência deles em Justiça. 


\section{Quadro 1 - Presença dos "mitos do estupro" em Justiça}

\begin{tabular}{|c|c|c|}
\hline MITO & COMO FUNCIONA & $\begin{array}{l}\text { PRESENÇA EM } \\
\text { JUSTIÇA }\end{array}$ \\
\hline Ela pediu por isso & $\begin{array}{l}\text { As causas do estupro são deslocadas do estuprador para a } \\
\text { vítima. Esse mito afirma que mulheres que se vestem, agem, se } \\
\text { comportam de uma determinada forma merecem ser estupradas. }\end{array}$ & $\begin{array}{l}\text { Parcialmente } \\
\text { presente }\end{array}$ \\
\hline $\begin{array}{l}\text { Não foi de fato um } \\
\text { estupro }\end{array}$ & $\begin{array}{l}\text { Esse mito normalmente está associado a casos de estupro } \\
\text { cometidos por pessoas com as quais a vítima já tenha se } \\
\text { relacionado anteriormente ou quando a vítima não se enquadra } \\
\text { como vítima inquestionável. }\end{array}$ & Ausente \\
\hline Ele não quis fazer isso & $\begin{array}{l}\text { Propaga a ideia de que o estupro foi um mal-entendido, um } \\
\text { acidente. }\end{array}$ & Ausente \\
\hline Ela queria & Representa a ideia de que 'no fundo, a vítima queria aquilo'. & Ausente \\
\hline Ela está mentindo & $\begin{array}{l}\text { Esse mito afirma que as mulheres mentem o tempo todo sobre } \\
\text { terem sido estupradas }[. . .] \text {, "que elas usam essa afirmação como } \\
\text { forma de se vingar de homens que traem ou que as ignoram, ou } \\
\text { para acobertarem a vergonha que sentem por terem dito sim" } \\
\text { (HARDING, 2015, p. 25). }\end{array}$ & Ausente \\
\hline Estupro é algo trivial & $\begin{array}{l}\text { Esse mito dissemina a ideia de que o estupro não é um problema } \\
\text { tão grande como as feministas querem que pareça, ou que ser } \\
\text { estuprada não é tão ruim quanto ser assaltada ou espancada, e } \\
\text { ainda que, se uma mulher não é virgem, então não deve ser nada } \\
\text { de mais quando alguém a força a ter relações sexuais. }\end{array}$ & Ausente \\
\hline $\begin{array}{l}\text { Estupro é um evento } \\
\text { desviante }\end{array}$ & $\begin{array}{l}\text { É a ideia de que o estupro é algo incomum, cometido apenas } \\
\text { por monstros com problemas psicológicos, e não por pessoas } \\
\text { conhecidas da vítima. }\end{array}$ & $\begin{array}{l}\text { Parcialmente } \\
\text { presente }\end{array}$ \\
\hline
\end{tabular}

Fonte: elaborado pela autora baseado em Harding (2015).

O primeiro dos mitos ('Ela pediu por isso’) está parcialmente presente em Justiça. Isso porque há cuidado com determinados aspectos. Em Justiça, Débora é estuprada em plena luz do dia, durante um bloco de Carnaval - como afirma Dworkin (1988), quando uma mulher anda sozinha à noite, ela não apenas corre o risco de sofrer abuso, como, de acordo com os valores da dominação masculina, está pedindo por isso. É importante ressaltar que o Carnaval funciona aqui como elemento neutralizador para observações sobre o comportamento ou a vestimenta da vítima. Ainda assim, Débora se afasta sozinha para um beco vazio, fumando maconha, o que abre espaço para a interpretação de culpabilização.

O segundo e o terceiro mitos ('Não foi de fato um estupro' e 'Ele não quis fazer isso') não são discutidos, pois, normalmente, estão presentes apenas quando o estuprador é alguém conhecido da vítima (ver sétimo mito). O mito 4 ('Ela queria') é, talvez, um do mais importantes do ponto de vista da representação da cena do estupro. Em outras produções da teledramaturgia da Rede Globo, como, por exemplo, Ligações perigosas, a emissora reforçou a ideia de que as mulheres se sentem excitadas quando forçadas a fazer sexo. Em Justiça, como já anteriormente comentado, a cena não erotiza o crime.

O quinto mito é relacionado à veracidade da acusação feita pela vítima. Na série, Débora não é questionada sobre ter sido ou não estuprada. Porém, esse mito propaga ainda a ideia de que mulheres que foram estupradas têm problemas emocionais. E Débora, em diversos momentos é apresentada como mentirosa e emocionalmente desestabilizada. O sexto mito ('Estupro é algo trivial') não é reforçado na série. Podemos dizer até que há um esforço de desconstrução desse mito, na medida em que vemos o quanto Débora foi afetada pelo estupro. 
O último dos mitos ('Estupro é um evento desviante') reforça, de forma geral, a noção de estupro como evento desviante. Destacamos: no que diz respeito à representação do estuprador, à ideia de que apenas homens doentes (sociopatas) são capazes de estuprar. Aqui, novamente a série parece ter sido cautelosa, mostrando, como já apontamos, Osvaldo como um homem frio, calculista, mas que tem amigos, que se relaciona bem com outras pessoas.

Isso é ainda confirmado na trama exibida às terças-feiras, na qual o irmão de Osvaldo, Firmino (Julio Andrade), conta à namorada sobre o irmão: “Osvaldo não é gente boa, não.” Ele relata que o irmão estuprou pela primeira vez quando ainda era menor de idade e que foi solto depois de pouco tempo, mas que voltou a fazer isso e nunca foi pego pela polícia. Firmino abomina os atos do irmão dizendo que é uma questão de caráter: "A pessoa roubar porque tá com fome eu entendo. Agora, ser estuprador, não."

A comparação entre os 'mitos do estupro' e as representações operadas em Justiça possibilita inicialmente dizer que o seriado realiza o que podemos denominar, a partir de uma perspectiva barthesiana, de uma escritura $^{13}$ do estupro (BARTHES, 2000, 2015). Consideramos que o texto de Justiça, entendido tanto em sua dimensão verbal como em sua dimensão visual, pode ser considerado um projeto de escritura por produzir um corte nos sentidos cristalizados pela linguagem sobre o estupro. A minissérie provoca um deslocamento das forças ideológicas que atravessam o projeto de estupro e, com isso, propõe para a sua audiência a figuração de um novo projeto político.

O corte axial produzido pela escritura de Justiça pode ser percebido no deslocamento dos estereótipos de masculinidade e feminilidade, centrais para a cultura do estupro. O estatuto da vítima é refigurado pela minissérie. A mulher abandona a vulnerabilidade existencial, marcada por uma fragilidade, e assume uma reação viril perante a violência sofrida. A performance da virilidade, esperada apenas de seu agressor e do homem que eventualmente partiria em defesa da vítima, passa a ser exercida por Débora em sua busca por vingança. Com isso, a personagem provoca um curto-circuito em uma longa empreitada política que ensina as mulheres a não se defenderem. A representação de Débora abandona a 'arte do servilismo' que forja o feminino como dócil, passivo e incapaz do exercício direto do poder.

Podemos considerar que a personagem de Débora desempenha o que Despentes (2016) denomina de um feminismo viril. Para a autora, o estupro só deixará de ser um organizador social e um dispositivo central da sexualidade quando as mulheres aprenderem que podem se defender e os homens reconhecerem que a força do feminino pode representar uma ameaça a sua integridade, caso queriam exercer suas 'pulsões masculinas' e forçar o sexo. Isso significa, em outras palavras, que a cultura do estupro só será superada quando os estereótipos de masculinidade e feminilidade que atravessam os sujeitos envolvidos forem desconstruídos.

Os deslocamentos nos papéis de gênero também são operados pela trama na representação de Osvaldo, o algoz, e Marcelo, o esposo. A virilidade de Osvaldo é questionada por Débora, na cena final do confronto. A vítima afirma que o estuprador só é 'valentão', quando está abusando de outras meninas, mas que com outros homens não parece ter a força de que outrora se vangloriava. Dessa forma, é retirado o exercício do poder do estuprador. Ele passa a ser visto como um homem fraco que precisa exercer sua força contra uma mulher para poder desempenhar a sua masculinidade

No que diz respeito a Marcelo, a pulsão viril de vingança, que se espera ser exercida pelo marido da vítima, não é praticada. O estupro, pela ótica da sociedade ocidental, é considerado historicamente um ato de violência não só contra a mulher, mas também contra o homem que seria o 'responsável' por ela.

13 A noção de escritura atravessa toda a obra de Barthes. A escritura indica um corte na forma usual de utilizar a linguagem, que seria da ordem da escrita (escrevências). Em linhas gerais, os textos de escritura romperiam com os estereótipos e deslocariam os sentidos para além da margem convencionada pela cultura hegemônica. A escritura teria o poder de subverter a ordem social e o funcionamento tradicional da linguagem. Para um panorama geral sobre a noção de escritura e sua diferença para com a escrevência, ler Perrone-Moisés (2005). 
A violência sexual seria um ataque à propriedade do pai ou do marido, representando uma afronta a sua masculinidade (RUBIN, 2017). Dessa forma, é esperada uma reação violenta em defesa da honra perante a constatação da violação da mulher ou filha. Contudo, Marcelo demonstra ser contrário à execução de um plano de vingança. A postura pacífica, entretanto, não indica que Marcelo desconsidere ser o 'dono' de Débora, já que ele se sente no direito de impor a maneira como ela deve se sentir e agir com relação ao estupro. O deslocamento no personagem de Marcelo acontece com relação à própria ideia de masculinidade. Ele é apresentado como um novo tipo de homem, contemporâneo, que não afirmaria sua masculinidade por meio da virilidade, vista como bárbara.

Dessa forma, as representações dos personagens de Débora, Osvaldo e Marcelo provocam um corte em uma cultura do estupro sustentada por estereótipos de papéis de gêneros baseados em uma economia da virilidade e da vulnerabilidade. Contudo, a narrativa apresentada por Justiça não escapa de todos os mitos da cultura do estupro. Como já apontamos, a trama reproduz parcialmente, por exemplo, a culpabilização da vítima por causa do seu comportamento considerado de risco. Com isso, podemos concluir que, embora Justiça busque produzir uma escritura sobre o estupro, a série acaba, em alguns momentos, reproduzindo elementos da cultura hegemônica. Justiça seria caracterizada por uma escritura-escrevência sobre o estupro. Ou seja, a minissérie opera a partir das lógicas da cultura da mídia, ora realizando um corte dos sentidos cristalizados, ora reforçando o estabelecido pela cultura do estupro.

\section{CONSIDERAÇÕES FINAIS}

Abordamos neste trabalho o modo como a narrativa do estupro foi representada na minissérie Justiça e ainda a repercussão que tal representação teve nas redes sociais. Nosso foco esteve no modo como o ato, a vítima e o estuprador são representados e na verificação da presença/ausência de alguns dos principais mitos relacionados ao estupro na narrativa. Cabe pontuar que a ficção seriada é o terceiro gênero mais exibido da televisão brasileira (13,4\%), ficando atrás apenas da informação $(25,9 \%)$ e do entretenimento (21\%). Os três gêneros totalizam mais de 60\% das horas de TV (KANTAR IBOPE MEDIA, 2015 apud VASSALO; ORÓZCO, 2016), dado que nos dá uma dimensão do tamanho da exposição à ficção seriada.

Começamos com a representação do estupro propriamente dito, na qual enquadramos três momentos: 1) o estupro do ponto de vista da vítima; 2) a vítima descrevendo o estupro; 3) o estuprador relembrando o ataque. Como já pontuamos na análise, o ataque é gráfico e impactou bastante os telespectadores, pesando a seu favor o fato de que não há erotização, ou romantização, mesmo do ponto de vista do estuprador. Apontamos aqui ainda outra questão: a exibição da cena não está ali apenas com a função de chocar. A história não se move em outras direções, o plot principal é o estupro e assim permanece, o que não torna essa uma representação sem sentido. É uma cena realista que opera com o estupro em um nível que já permeia nossos imaginários, mas que é, ao mesmo tempo, a ocorrência menos comum do crime: o estupro cometido pelo estranho na rua. A descrição que Débora faz do ato em outro momento da trama causa menos impacto, mas também foi uma cena que chamou atenção dos telespectadores e nos parece interessante do ponto de vista representacional, por tratar não do contexto do estupro, mas do sentir-se violada, vulnerável, algo que pode aproximar mais a personagem enquanto vítima das sensações de vítimas reais. Por fim, reforçamos a necessidade de cautela nas representações de estupro, que não pode ser entendido apenas como um bom plot para atrair audiência e/ou provocar reviravoltas na trama.

Há ainda a representação da vítima. Um ano após o ataque, Débora mostra, clara e gradativamente (à medida que a situação a faz reviver o estupro e se ver em frente ao estuprador) as sequelas. Consequências físicas, emocionais. E embora, em alguns momentos, a personagem tenha sido interpretada pelo público como louca e desequilibrada, Débora conquistou a simpatia e sensibilizou o público. 
As representações do algoz e da vítima sofrem rupturas, mas também apresentam continuidades com relação à lógica cristalizada da cultura do estupro. Sendo a violência sexual um problema de saúde pública, e tendo em vista que os mitos representacionais do estupro interpelam o campo da saúde como um todo, criando um ciclo de múltiplas camadas de violência contra o corpo da mulher, a análise representacional de Justiça, a partir de um olhar feminista, é fundamental para produzir uma reflexão crítica sobre os mitos que naturalizam papéis e estereótipos de gênero. Ao entendermos o estupro como um acontecimento sistêmico na sociedade, ações midiáticas de deslocamento de sentido - tais como operadas em Justiça - e uma reflexão sobre essas produções em circulação - tal como apresentamos neste artigo - seriam importantes para incentivar um diálogo público que possibilite uma mudança de mentalidade.

Interessa-nos, ainda, observar alguns outros tópicos conversacionais suscitados pela minissérie. São eles: 1) importância da temática; 2) cultura do estupro; 3) violência sexual sendo paga com violência sexual. Entre os comentários coletados, encontramos muitas mensagens que destacavam a importância de retratar essa temática "Racismo e estupro num mesmo capítulo, é tudo aquilo que temos que ver na TV brasileira, pois precisa ser mostrado, discutido, combatido \#Justiça”. Uma outra recorrência é de comentários que denunciam a cultura do estupro, seja pela desconstrução de mitos ou pelo reforço da existência da cultura do estupro "Será que os moralistas pensaram que ela merecia ser estuprada porque tava de roupa curta curtindo a vida e fumando um? \#Justiça" (MARTINS, 2016). Por fim, há ainda um último tópico conversacional recorrente: a ideia de que a violência sexual deve ser vingada com violência sexual. Percebemos que, em muitos comentários, os telespectadores deixam claro que Osvaldo tinha que ser estuprado, que a própria Débora deveria ter articulado isso como parte de sua vingança ou ainda que ele merecia ser preso para ser estuprado na cadeia: "Debora poderia ter feito com o estuprador, igual em Doce Vingança, enfiado o pedaço de pau... vcs sabem onde!!! \#Justiça'14." (F., 2016)

Gostaríamos de retornar a Barthes para concluir nossa reflexão sobre a representação da cultura do estupro em Justiça. O autor reflete, quinze anos após a publicação do seu livro Mitologias, que é necessário não somente descortinar os mitos e desmascarar os seus efeitos (movimento que ele havia realizado inicialmente): o objetivo deveria ser tentar fissurar, abalar a própria representação (BARTHES, 1977). De certa forma, a trama de Justiça, ao operar um corte nos estereótipos do estuprador e do marido como viris e da vítima como vulnerável, está não só denunciando uma artificialidade nos sentidos consagrados, mas também superando o modelo cristalizado do uso da linguagem. Justiça demonstra como a representação midiática pode ser tanto produtora de mitos sobre o estupro quanto questionadora dos alicerces da cultura que os sustenta. Afinal, como nos lembra Perrone-Moisés (1983), o desmistificador não está acima ou a salvo da cultura midiática - está inserido nela.

\section{REFERÊNCIAS}

AHLF, Chloe. "She's dead - wrapped in plastic": unwrapping rape culture in Twin Peaks. 2013. 25 f. Trabalho de conclusão de curso (Bachelor of Arts) - University of Minnesota, Minneapolis, 2013.

ANUÁRIO BRASILEIRO DE SEGURANÇA PÚBLICA 2020. São Paulo: Fórum Brasileiro de Segurança Pública, 2020. Disponível em: https://forumseguranca.org.br/wp-content/uploads/2020/10/anuario-14-2020-v1interativo.pdf. Acesso em: 12 fev. 2021.

ARAÚJO, Inesita Soares; CARDOSO, Janine Miranda. Comunicação e saúde. Rio de Janeiro: Editora Fiocruz, 2007.

BARBOSA, Marialva. Comunicação e método: cenários e práticas de pesquisa. Rio de Janeiro: Mauad X, 2020.

14 Referência ao filme I Spit On Your Grave (Doce Vingança, 1978) que é famoso por usar uma fórmula clássica do estupro e vingança. 
Reciis - Revista Eletrônica de Comunicação, Informação \& Inovação em Saúde, Rio de Janeiro, v. 15, n. 3, p. 614-635, jul.-set. 2021 [www.reciis.icict.fiocruz.br] e-ISSN 1981-6278

BARTHES, Roland. Aula. São Paulo: Cultrix, 2013.

BARTHES, Roland. Mitologias. Rio de Janeiro: DIFEL, 2010.

BARTHES, Roland. Mudar o próprio objeto. In: LUCCIONI, Gennie et al. Atualidade do mito. São Paulo: Duas Cidades, 1977. p. 11-14

BARTHES, Roland. O grau zero da escrita. São Paulo: Martins Fontes, 2000.

BARTHES, Roland. O prazer do texto. São Paulo: Perspectiva, 2015.

BRINSON, Susan L. The use and opposition of rape myths in prime-time television and dramas. Sex Roles, [s. I.], v. 27, p. 359-375,1992. DOI: https://doi.org/10.1007/BF00289945. Disponível em: https://link.springer.com/ article/10.1007\%2FBF00289945. Acesso em: 15 abr. 2020.

BRINSON, Susan L. TV rape: the representation of rape in prime-time television dramas. 1990. $199 \mathrm{f}$. Dissertação (Ph. D) - University of Missouri-Columbia, Columbia, 1990.

BUCHWALD, Emile; FLETCHER, Pamela; ROTH, Martha (Ed.). Transforming a rape culture. Minneapolis: Milkweed Editions, 2005.

CAVALCANTI, Gêsa. Representação dos Mitos do Estupro na Minissérie Justiça. In: CONGRESSO DE CIÊNCIAS DA COMUNICAÇÃO NA REGIÃO NORDESTE, 19., Fortaleza, 29 jun a 01 jul. 2017. Anais [...]. Fortaleza, 2017.

DESPENTES, Virginie. Teoria King Kong. São Paulo: N-1 Edições, 2016.

DWORKIN, Andrea. Letters From a War Zone. New York: Lawrence Hill Books, 1988.

F., Marcia. Debora poderia ter feito com o estuprador, igual em Doce Vingança, enfiado o pedaço de pau... vcs sabem onde!!! \#Justiça. Macaé, 22 set. 2016. Twitter: @bymarciaf. Disponível em: https://twitter. com/bymarciaf/status/779139152751263744. Acesso em: 10 ago. 2021.

FREUD, Sigmund. Lembranças encobridoras (1899). In: FREUD, Sigmund. Sigmund Freud: obras completas. Rio de Janeiro: Imago Editora, 1996a. v. III, p.267-285.

FREUD, Sigmund. O mecanismo psíquico do esquecimento. In: FREUD, Sigmund. Sigmund Freud: obras completas. Rio de Janeiro: Imago Editora,1996b. v. III, p. 259-266.

FREUD, Sigmund. Recordar, repetir e elaborar: novas recomendações sobre a técnica da Psicanálise II. In: FREUD, Sigmund. FREUD, Sigmund. Sigmund Freud: obras completas. Rio de Janeiro: Imago Editora, 1990. v. XII, p. 191-203.

GUERRERO, Rodrigo. La violencia desde la perspectiva de la salud pública. In: BRICEÑO-LEON, Roberto; MINAYO, Maria Cecília; COIMBRA JR., Carlos. (Org.). Salud y Equidad: una mirada desde las ciencias sociales. Rio de Janeiro: Editora Fiocruz, 2000. p. 147-157.

HALL, Stuart. Representação e cultura. Rio de Janeiro: Ed. PUC-Rio; Apicuri, 2016.

HARDING, Kate. Asking for it: the alarming rise of rape culture - and what we can do about it. Boston: Da Capo Lifelong Books, 2015.

MAGESTRO, Molly Ann. Assault on the small screen: representations of sexual violence on prime-time television dramas. Washington, DC: Rowman \& Littlefield Publishers, 2015.

MARTINS, Sami. Será que os moralistas pensaram que ela merecia ser estuprada porque tava de roupa curta curtindo a vida e fumando um? \#Justiça. [S. I.], 25 ago. 2016. Twitter: exaustah @samimarrrrtinss. Disponível em: https://twitter.com/samimarrrtinss/status/768992746153672704. Acesso em: 10 ago. 2021.

MEYERS, Marian. News coverage of violence against women. Londres, Sage Publications, 1997.

PERRONE-MOISÉS, Leyla. Roland Barthes: o saber com sabor. São Paulo: Editora Brasiliense, 1983.

PERRONE-MOISÉS, Leyla. Texto, crítica, escritura. São Paulo: Martins Fontes, 2005. 
RICOEUR, Paul. O Justo: ou a essência da justiça. Lisboa: Instituto Piaget, 1995.

RODRIGUES, Edvaldo; MENEZES, Maria Eduarda; BANDEIRA, Àlamo. Mulheres na geladeira: a vulnerabilidade das super-heroínas no universo das histórias em quadrinhos. In: CONGRESSO BRASILEIRO DE CIÊNCIAS DA COMUNICAÇÃO, 38., Rio de Janeiro, 4 a 7 set. 2015. Anais [...]. Rio de Janeiro: Intercom, 2016.

RUBIN, Gayle. Políticas do sexo. São Paulo: Ubu Editora, 2017.

SACRAMENTO, Igor; BORGES, Wilson Couto. Representações midiáticas da saúde. Rio de Janeiro: Editora Fiocruz, 2020.

SARTI, Cynthia Corpo, violência e saúde: a produção da vítima. Sexualidad, Salud y Sociedad, Rio de Janeiro, n. 1, p. 89-103, 2009. Disponível em: https://www.e-publicacoes.uerj.br/index.php/ SexualidadSaludySociedad/article/view/12. Acesso em: 29 jul. 2021.

SODRÉ, Muniz. A ciência do comum: notas para o método comunicacional. Petrópolis: Vozes, 2014.

SODRÉ, Muniz. Antropológica do espelho: uma teoria da comunicação linear e em rede. Petrópolis: Vozes, 2009.

VASSALO, Immacolata; ORÓZCO, Gomes. (Orgs.). (Re)invenção de gêneros e formatos da ficção televisiva: Anuário Obitel, 2016. Porto Alegre: Sulina, 2016.

TODOROV, Tzvetan. Los abusos de la memoria. Barcelona: Paidós, 2000.

VOLÓCHINOV, Valentin. Marxismo e filosofia da linguagem. São Paulo: Editora 34, 2018.

WINN, Julia. Perpetuating rape myths: representations of rape in the media. [S. I.: s. n.], 2011. Disponível em: https://studylib.net/doc/6746609/perpetuating-rape-myths--representations-of. Acesso em: 29 jul. 2021. 